\title{
Botanical Composition of Eland and Goat Diets on an Acacia-grassland Community in
}

Kenya

\section{JOHN C. NGE'THE AND THADIS W. BOX}

Highlight: A study of goat and eland diets on the Kiboko Range Research Station, Kenya, showed that diets of both animal species consisted of leaves from relatively few plant species. Six of the 41 species available consistently provided the bulk of the diets of both goats and elands. Although elands utilized a wide variety of plants, they consumed a larger proportion of grasses than goats. Elands are mixed feeders (grazers and browsers), grazing both during the wet and dry period. The diets of both kinds of animals were more diverse during the growing season (February through May), compared to the dry season (July through October). This reflected the greater variety of available forage during the wet season.

The rangelands of Kenya occupy about 50 million hectares where inadequate and erratic rainfall causes a high incidence of crop failure. The average annual precipitation is below 750 $\mathrm{mm}$ with 48.3 million hectares receiving less than $500 \mathrm{~mm}$ annually. Most ranges are utilized by a combination of various species of wild life and various classes of livestock. In most areas, wildlife migrations and seminomadic movements of cattle, goats, sheep, and camels alternate use on wet season and dry season ranges. The current trends in increasing the number of individual fixed-base ranches has led to more intensified year-long grazing. If range deterioration is to be avoided, sound management must be practiced.

Effective animal protein production depends on identification of palatable and nutritious plants coupled with parallel adjustments in animal management practices to maintain optimum sustained productivity of the desirable plants. Botanical composition of diets of the common eland Taurotragus oryx and domestic Galla goats in an acacia-grassland community are reported as a tool for more efficient management.

The common eland, a Bovidae (Lydekker and Blaine, 1914), is native to Africa (Fig. 1). It occurs in most African states south of Sahara (Treus and Kravchenko, 1968). The adult animal is heavily built and reaches almost 2 meters at the shoulder. All animals have the black garter on the forelegs and a black strip running down the back. Young animals are reddish brown, but bulls darken with age. Elands are docile

Authors are graduate student, Range Science Department, Utah State University, Logan, and dean, College of Natural Resources, and professor, range science, Utah State University, Logan. Nge'the is now at Kiboko Range Research Station, Makindu, Kenya.

Manuscript received July 3, 1975.

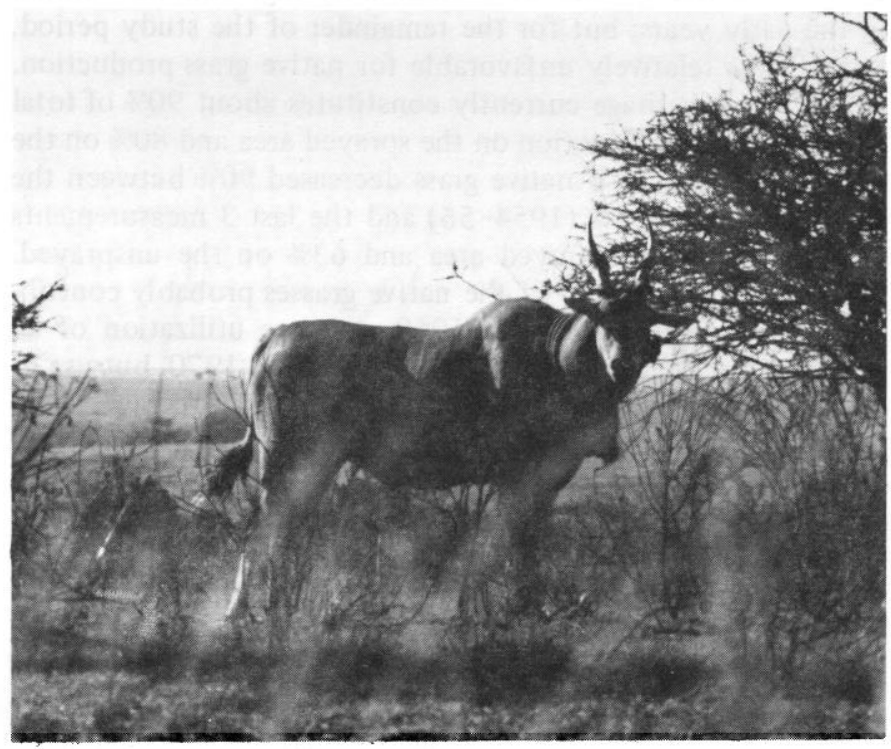

Fig. 1. Eland.

Photo by L. Hendzel.

and gregarious animals. In captivity elands are gentle, silent animals with a potential for domestication. Several optimistic views (Talbot and Talbot, 1963; Dasmann, 1964a; Russel, 1972) have indicated that ranching elands in Kenya's rangelands offers an excellent possibility to expand the tight meat supply in the country. This study was partly designed to elucidate the feasibility of ranching elands. There is some indication that the eland's diet is similar to that of goats. Therefore, the relationship of the eland's diet to that of the economically important goat should be examined before eland ranches are recommended.

\section{Study Area}

This study was conducted on Kiboko Range Research Station (Kenya) situated $164 \mathrm{~km}$ south of Nairobi, $2^{\circ} 30^{\prime} \mathrm{S}$, $37^{\circ} 50^{\prime} \mathrm{W}$. The general elevation is about 1,000 meters above sea level. The area is in ecological zone IV (Pratt et al., 1966). This zone is characterized by scattered Acacia tortilis and Commiphora riparia trees in the upper story with tall tropical grasses in the matrix.

Climatic parameters for Kiboko area are typical of many monsoonal tropical rangelands. The data used here are for Makindu, adjacent to Kiboko. The average annual rainfall for 69 years is $615 \mathrm{~mm}$, with most of the rain falling in four consecutive months. In $1972,57.8 \%$ of the $398.4 \mathrm{~mm}$-rainfall 
was received in November, while $85.1 \%$ fell in 3 months (October, November, December). The days are hot and nights are warm. The mean maximum temperature range for $1972-1973$ was $27.2-32.6^{\circ} \mathrm{C}$ and mean minimum range was $13.2-18.6^{\circ} \mathrm{C}$. Pan evaporation figures for the same period ranged $140-240 \mathrm{~mm}$ per month, the relative humidity range was 70.1-87.4\% except for October and November 1973, when it was $35.4 \%$ and $54.4 \%$, respectively.

\section{Procedure}

Five sub-adult elands captured in July/August 1972 were tamed and trained through January. Ocular estimates of plants consumed by elands were conducted two mornings each week, for half an hour, from the third week in February through May. All animals were used in rotation, with only one animal observed each period. Forage availability in terms of quality and quantity was apparcntly not a limiting factor during this period.

The procedure involved leading animals to the pastures and allowing them to settle for about half an hour before observations were initiated. Plant species selected were noted, identified, and the number recorded following the procedure of Bjugstad et al. (1970). To avoid predation, animals were corralled at night and grazed during the day. Wallmo and Neff (1970) concluded that semitame pronghorn antelope selected the same principal plants in the same proportions as their wild counterparts. In this study, taming was assumed to have negligible effect on forage selection.

Five elands, three fitted with esophageal cannulae, and 15 goats, two fitted with esophageal cannulae, were used to graze six fenced, 1-hectare paddocks from July through October. The fistulation procedure adopted in both animal types was essentially the same and followed Van Dyne and Torell (1964). Two paddocks were grazed by elands, two by goats, and two by a combination of both animal types (Table 1). Vegetation in each paddock was sampled before and after grazing to determine availability (cover and biomass) and utilization. Cover estimates were conducted using line intercept method along six 100-meter transects in each paddock, while biomass was calculated from material clipped from 45 $\mathrm{m}^{2}$ quadrats stratified along nine 100-m transects in each paddock.

Microscopic slides prepared from fistula samples collected two days every week from July through October were used in evaluating diet composition. Species composition in the diets
Table 2. Forage species consumed by elands during the favorable period-based on ocular observations.

\begin{tabular}{|c|c|c|}
\hline Species $^{1}$ & $\begin{array}{l}\text { Total } \\
\text { bites }\end{array}$ & $\begin{array}{l}\text { Relative } \\
\text { acceptance } \\
\text { index } \%^{2}\end{array}$ \\
\hline Dijitaria milanjiana $(\mathrm{Gr})$ & 710 & 11.3 \\
\hline Grewia similis $(\mathrm{Br})$ & 485 & 7.7 \\
\hline Eustachyus paspaloides $(\mathrm{Gr})$ & 401 & 6.4 \\
\hline Bothriochloa insculpta $(\mathrm{Gr})$ & 388 & 6.2 \\
\hline Panicum maximum $(\mathrm{Gr})$ & 384 & 6.1 \\
\hline Themeda triandra $(\mathrm{Gr})$ & 271 & 4.3 \\
\hline Commiphora africana $(\mathrm{Br})$ & 251 & 4.0 \\
\hline Disperma kilimandscharica $(\mathrm{Br})$ & 230 & 3.7 \\
\hline Cynodon dactylon $(\mathrm{Gr})$ & 213 & 3.4 \\
\hline Grewia bicolor $(\mathrm{Br})$ & 200 & 3.2 \\
\hline Panicum deustum (Gr) & 166 & 2.6 \\
\hline Acacia brevispica $(\mathrm{Br})$ & 165 & 2.6 \\
\hline Bidens pilosa $(\mathrm{F})$ & 163 & 2.6 \\
\hline Combretum molli $(\mathrm{Br})$ & 140 & 2.2 \\
\hline Chloris roxburghiana (Gr) & 139 & 2.2 \\
\hline Acacia tortilis $(\mathrm{Br})$ & 126 & 2.0 \\
\hline Acacia senegal $(\mathrm{Br})$ & 113 & 1.8 \\
\hline Dolichos molasanus $(\mathrm{F})$ & 110 & 1.8 \\
\hline Dichrostachyus cinerea $(\mathrm{Br})$ & 98 & 1.6 \\
\hline Grewia vilosa $(\mathrm{Br})$ & 85 & 1.4 \\
\hline Cucumis spp. (F) & 84 & 1.3 \\
\hline Aerva persica $(\mathrm{F})$ & 81 & 1.3 \\
\hline Commiphora riparia $(\mathrm{Br})$ & 77 & 1.2 \\
\hline Sida ovalis $(\mathrm{Br})$ & 73 & 1.2 \\
\hline Cenchrus ciliaris $(\mathrm{Gr})$ & 68 & 1.1 \\
\hline Desmodium spp. (F) & 67 & 1.1 \\
\hline Dalbergia malanoxylon $(\mathrm{Br})$ & 63 & 1.0 \\
\hline
\end{tabular}

${ }^{1} \mathrm{Gr}=$ grass $; \mathrm{Br}=$ browse $; \mathrm{F}=$ forb.

${ }^{2}$ Relative acceptance index is the species total bites divided by the total number of all bites

was determined following procedures outlined by Sparks and Malechek (1968). Identification hased on epidermal characteristics involved matching epidermal characteristics of fistula samples with reference slides prepared from all species in the pastures (Hansen, 1971; Hansen et al., 1973; Storr, 1961; Davies, 1959).

\section{Results and Discussion}

Sixty-three plant species were eaten by elands during the favorable period. Twenty-seven species with a relative acceptance index higher than $1 \%$ (Table 2) represented $85 \%$ of the

Table 1. Total cover and herbage biomass in six 1-hectare paddocks before grazing, including only the major forage species with average plant cover greater than $1 \%$.

\begin{tabular}{|c|c|c|c|c|c|c|}
\hline \multirow[b]{2}{*}{ Species and measurements ${ }^{1}$} & \multicolumn{6}{|c|}{ Paddocks } \\
\hline & 1 & 2 & 3 & 4 & 5 & 6 \\
\hline Animal type and & Goats & Goats & Both & Both & Elands & Elands \\
\hline month used & July & Sept. & Aug. & Oct. & July & Sept. \\
\hline Total cover $(\%)$ & 73.2 & 90.8 & 70.5 & 70.2 & 62.4 & 69.4 \\
\hline Herbage biomass ( $\mathrm{kg} /$ ha air dry) & 4130 & 4020 & 3760 & 4480 & 4130 & 4220 \\
\hline \multicolumn{7}{|l|}{ Species cover $(\%)$} \\
\hline Themeda triandra $(\mathrm{Gr})$ & 35.9 & 28.9 & 40.4 & 37.8 & 25.3 & 29.2 \\
\hline Digitaria milanjiana $(\mathrm{Gr})$ & 31.1 & 38.2 & 11.8 & 18.2 & 16.8 & 13.8 \\
\hline Eragrostis caespitosa $(\mathrm{Gr})$ & 3.2 & 4.4 & - & 2.3 & 1.4 & - \\
\hline Eustachyus paspaloides (Gr) & 2.2 & - & 1.0 & 1.2 & 2.2 & 2.4 \\
\hline Bothriochloa insculpta $(\mathrm{Gr})$ & 2.1 & 4.5 & 3.4 & 2.8 & 5.9 & 6.5 \\
\hline Sehima nervosum $(\mathrm{Gr})$ & 1.1 & - & - & - & - & 4.7 \\
\hline Cenchrus ciliaris $(\mathrm{Gr})$ & - & 1.1 & 1.2 & 1.7 & 1.8 & 1.4 \\
\hline Commiphora africana $(\mathrm{Br})$ & 3.5 & 2.1 & 2.4 & 1.5 & - & 1.1 \\
\hline Disperma kilimand scharica $(\mathrm{Br})$ & 2.4 & 1.2 & - & 1.2 & - & - \\
\hline Acacia tortilis $(\mathrm{Br})$ & 1.9 & 3.1 & 4.4 & 3.7 & 1.1 & 4.7 \\
\hline Acacia senegal $(\mathrm{Br})$ & 1.1 & 1.1 & - & - & - & - \\
\hline Grewia vilosa $(\mathrm{Br})$ & - & - & 1.3 & - & - & - \\
\hline
\end{tabular}

\footnotetext{
${ }^{1} \mathrm{Gr}=$ graze; $\mathrm{Br}=$ browse.
} 
total bites. Thirty-six species had a relative acceptance index of less than $1 \%$ and represented only $15 \%$ of the total bites. However, only 13 species comprised $63 \%$ of the total bites. Grasses comprised $48 \%$ and browse $52 \%$ of the total bites. Consequently, elands under Kiboko conditions, grazed as much as they browsed. Kerr et al. (1970), using animalminutes method, concluded that elands spent $93 \%$ of their time in the field browsing and 7\% grazing. Skinner (1966) concluded that, though elands graze or browse depending on habitat quality, they prefer to browse. Some of the species eaten are reputed to be poisonous, while others have medicinal properties. Crotolaria species are reported to be poisonous, while Albizia antihelmintica is used for treating Helminthes infection locally.

Results from fistula sample analysis indicated that relatively few species comprised the bulk of the diets. In July when animals grazed separately, eight species, three grasses and five browse species, comprised $66 \%$ of elands' diets (Fig. 2a).

$\%$ species composition in the diet

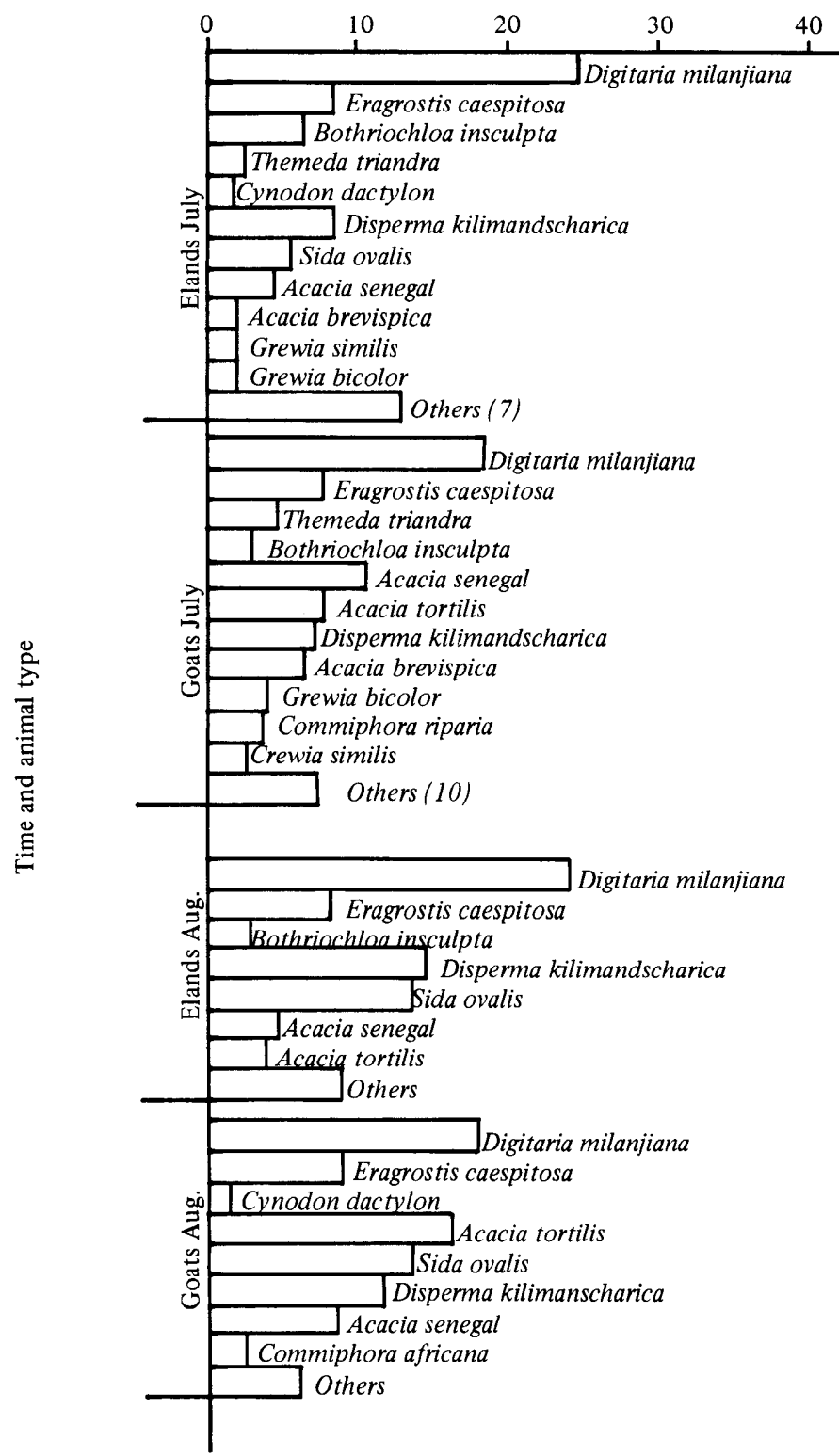

Fig. 2a. Forage species and their relative contribution in the diets of elands and goats in July and August.
Digitaria milanjiana was the major diet component, contributing $25 \%$ and $18 \%$ of elands' and goats' diets, respectively. Eragrostis caespitosa and Disperma kilimandscharica were equally important in both animal types.

In August all animals grazed together. The bulk of goats' diet was comprised of six species: four browse species and two grasses constituted $75 \%$ of the diet. Five species, three browse species and two grass species, comprised $60 \%$ of the eland diets (Fig. 2a).

Goats and elands grazed separately in September. Grasses featured very importantly in elands' diets, with browse constituting only about $10 \%$ of the total diet. Browse constituted $35 \%$ of goats' diets. Digitaria milanjiana constituted $40 \%$ in eland diets and $28 \%$ in goats' diets (Fig. 2b).

In October both animal types grazed together. The diet composition for both goats and elands was limited to very few species. Four species comprised $77 \%$ of the goats' diet. Digitaria constituted $26 \%$, A. tortilis $22 \%$, Disperma $15 \%$, and A. senegal $13 \%$ of the diets. The other six plant species comprised only $23 \%$ of the diet (Fig. 2b). For elands, grasses constituted the bulk of the diet. Three grasses, Digitaria, Bothriochloa, and Eragrostis caespitosa constituted $56 \%$ of the diet composition. Two browse species, Disperma and $A$. tortilis, made up $17 \%$ of the diet composition. Disperma was the major component.

Themeda triandra was the most abundant species in the pastures (Table 1) but made only a modest contribution in eland and goat diets (Fig. 2a and $2 \mathrm{~b}$ ). The results indicated that Digitaria milanjiana was the species most preferred by both animal types. Based on species contribution in eland and goat diets and species percent cover in the community, it is apparent that Digitaria milanjiana, Eragrostis caespitosa, Disperma, Acacia tortilis, Bothriochloa insculpta, and Acacia senegal are the key species in this area.

Grass and browse leaves constituted more than $80 \%$ of eland and goat diets from July through October (Figs. 3 and

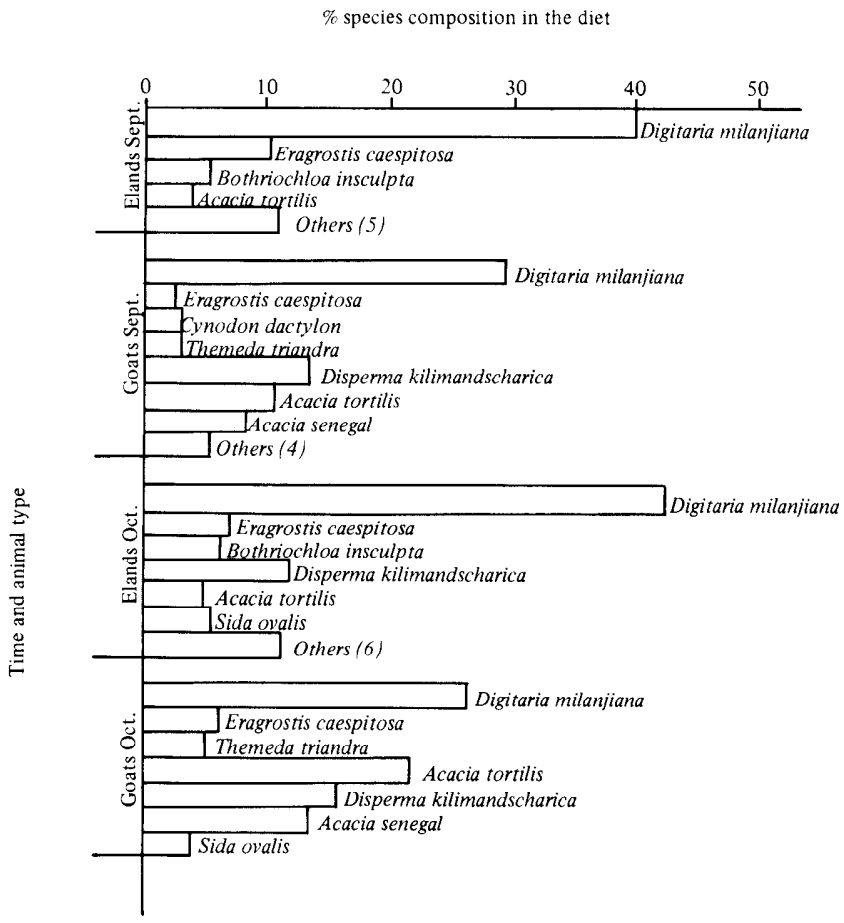

Fig. 2b. Forage species and their relative contribution in the diets of elands and goats in September and October. 
(a) browse stems (Dbrowse leaves (C)grass stems (D)gass sheaths () grass leaves

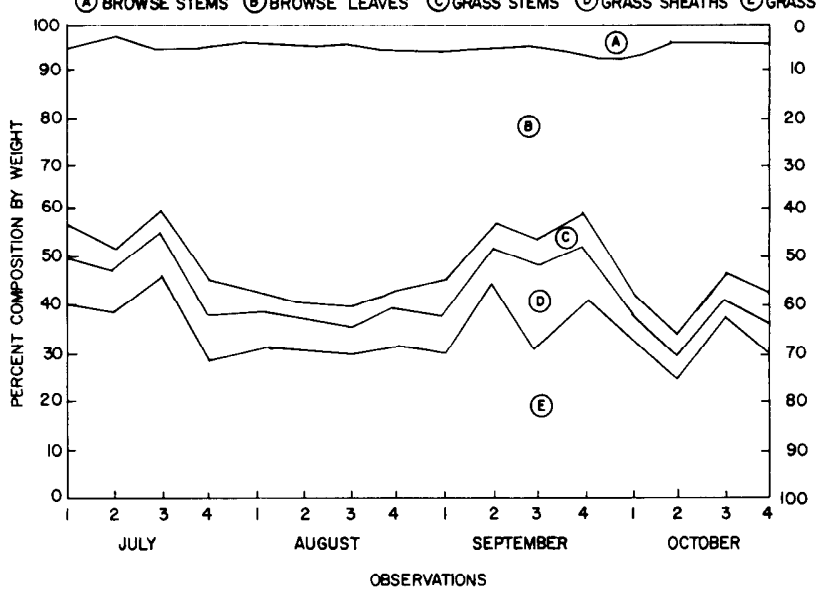

Fig. 3. Forage classes in the diets of goats from July through October, based on fistula samples.

4). Grass sheaths and grass and browse stems are minor diet components. Under the Kiboko environment, goats consumed more browse leaves, particularly Acacia leaves, than elands. Averaged over the entire study, the goats' diets contained $35 \%$ grass leaves and $45 \%$ browse leaves. Grass sheath, grass stems, and browse stems comprised $7 \%, 4 \%$, and $4 \%$ of the diets, respectively. In contrast, the elands consumed considerable amounts of grass leaves. Their diet was comprised of $54 \%$ grass leaves, $26 \%$ browse leaves, $11 \%$ grass sheaths, $5 \%$ grass stems, and $4 \%$ browse stems.

Percent composition by weight of various forage species in the diets exhibited high temporal variation. Acacia tortilis and Digitaria milanjiana (Figs. 2a and $2 \mathrm{~b}$ ) illustrate this point. Acacia tortilis, a thorny multilayered bush during the early growth stages, and the most abundant dicot in the study paddocks, is moderately palatable. It occurred in most samples collected. Samples from goats contained higher proportion of Acacia leaves compared to samples collected from elands. Goats consumed a maximum amount of Acacia leaves in October, when most dicots had shed their leaves to avoid drought stress (Figs. 2a and $2 \mathrm{~b}$ ). Elands consumed low and almost constant amounts of Acacia leaves. Goats, with their more tapering mouthparts and prehensile lips, work their way through spines, picking the leaves and avoiding the spines. In contrast, elands place forage items in the mouth on top of the tongue, close the jaws, and pull the head horizontally towards or away from the chest. The tongue is not used for sweeping material in to the mouth.

Digitaria milanjiana, the second most common species in the ground flora, was the major component in the diets of both animal types throughout the study. Its distribution in the diets showed that intake increased with the severity of the dry season. Elands consumed more Digitaria than goats. Goats browsed more in the morning and grazed more in the afternoon. This seemed abnormal since grasses were coarse and dry in the afternoon compared to the moist, cool conditions in the morning. Elands grazed heavily in the morning, taking advantage of the cool, wet grasses.

The overall results indicated that elands are mixed feeders, with a high capacity to utilize a wide variety of species. Van Zyl (1965) reported that elands browsed $76.5 \%$ and grazed $23.5 \%$ of their time in the field, while Lamprey (1963) concluded that elands selected $70 \%$ grasses and $30 \%$ browse species. Kerr et al. (1970) reported that grasses were minor

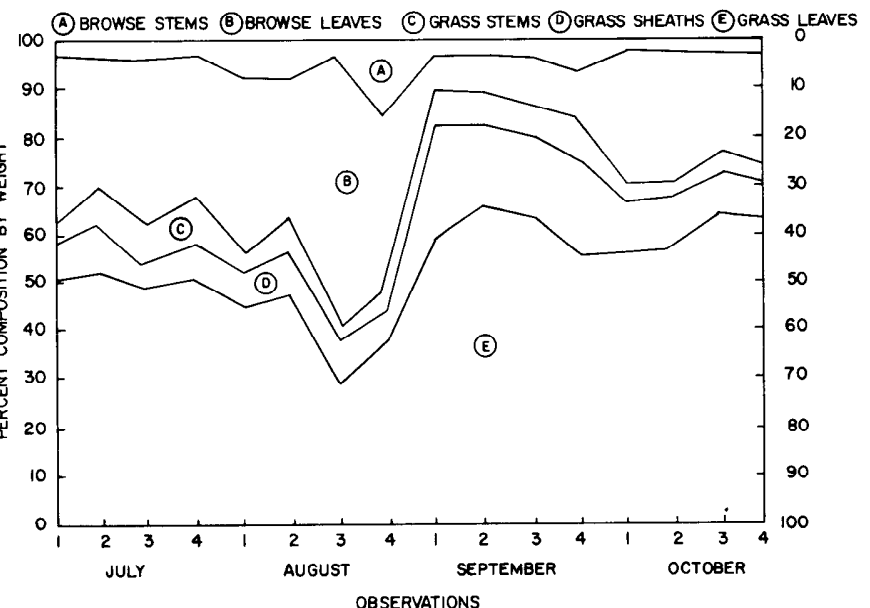

Fig. 4. Forage classes in the diets of elands from July through October, based on fistula samples.

forage components for elands. The conflicting conclusions imply that intake is largely dictated by availability. Further, they confirm the observation that elands are capable of utilizing a wide variety of species.

\section{Literature Cited}

Bjugstad, A. J., Hewlett, Crawford, and D. L. Neal. 1970. Determining forage consumption by direct observation of domestic grazing animals. U.S. Dep. Agr. Misc. Pub. 1147. p. 101-104.

Davies, K. 1959. The use of epidermal characteristics for the identification of grasses in leafy stage. J. Brit ish Grass Soc. 14:7-16.

Dasmann, R. F. 1964a. African game ranching. Oxford Pergamon Press.

Hansen, R. M. 1971. Drawing of tissues of plants found in herbivore diets and litter of grasslands. Range Sci. Dep., Colorado State Univ., Fort Collins, Colo. 71 p.

Hansen, R. M., D. G. Peden, and R. W. Rice. 1973. Discerned fragments in feces indicates (sic) diet overlap. J. Range Manage. 26:103-105.

Kerr, J. A., V. J. Wilson, and H. H. Roth. 1970. St udies on agricultural utilization of semi-domesticated eland (Taurotragus oryx) in Rhodesia. Rhod. J. Agr. Res. 8:71-76.

Lamprey, H. F. 1963. Ecological separation of the large mammal species in Tarangire Game Reserve, Tanganyika. E. Africa Wildl. J. 1:63-92.

Lydekker, R., and G. Blaine. 1914. Catalogue of the ungulate mammals in the British Museum (Natural History 2 and 3. British Museum, London.

Pratt, D. J., P. J. Greenway, and M. D. Gwyne. 1966. A classification of East African rangelands. J. Applied Ecol. 3:369-382.

Russel, K. 1972. Will antelope recapture Africa? New Scientist 640-643.

Skinner, J. D. 1966. An appraisal of the eland (Taurotragus oryx) for diversifying and improving animal production in Southern Africa. Africa Wildlife 20:29-40.

Sparks, D. R., and J. C. Malechek. 1968. Estimating percentage dry weight in diets using microscopic technique. J. Range Manage. 21:264-265.

Storr, G. M. 1961. Microscopic analysis of feces, a technique for ascertaining the diet of herbivorous mammals. Aust. Biol. Sci. 14:157-164.

Talbot, L. M., and M. H. Talbot. 1963. The high biomass of wild ungulates in East African savanna. Trans. 28th North Amer. Wildl. Conf. 465-476.

Treus, V. C., and D. Kravchenko. 1968. Methods of rearing and cconomic utilization of eland in the Askaniya-nova Zoological Park. Symp. 200. Soc. Land. No. 21-395-411.

Van Dyne, G. M., and D. T. Torell. 1964. Development and use of the esophageal fistula. A review. J. Range Manage. 7:7-19.

Van Zyl, J. H. M. 1965. The vegetation of S. A. Lombard Nature Reserve and its utilization by certain antelopes. Zoological Africa. $1: 55$.

Wallmo, D. C., and D. J. Neff. 1970. Direct observations of tame deer to measure their consumption of natural forage. Dep. Agr. Misc. Pub. 1147. p. 105-110. 